\title{
Casein Breakdown in Terrincho Ovine Cheese: Comparison with Bovine Cheese and with Bovine/Ovine Cheeses
}

\author{
I. M. P. L. V. O. Ferreira, ${ }^{\star 1}$ C. Veiros, ${ }^{*}$ O. Pinho, ${ }^{\star} †$ A. C. A. Veloso, $\ddagger$ A. M. Peres, $\ddagger$ and A. Mendonça \\ ${ }^{*}$ REQUIMTE-Serviço de Bromatologia, Faculdade de Farmácia, Universidade do Porto, R. Aníbal Cunha 164, $4050-047$ Porto, Portugal \\ †Faculdade de Ciências da Nutrição e Alimentação, Universidade do Porto, Rua Dr. Roberto Frias, 4200-465 Porto, Portugal \\ †Escola Superior Agrária de Bragança-Instituto Politécnico de Bragança, Quinta de Santa Apolónia, Apartado 1172, \\ 5301-855 Bragança, Portugal
}

\begin{abstract}
Terrincho cheese is an uncooked, pressed cheese made from raw whole ovine milk from the "Churra da Terra Quente" breed. It requires a minimum ripening time of $30 \mathrm{~d}$. A detailed evaluation of the effect of ripening time on the breakdown of the casein fractions, along with the formation of major breakdown products of casein hydrolysis, was monitored by HPLC to contribute to a more complete characterization of this product. In 30 -d-old cheeses, only $20 \%$ of $\alpha_{\mathrm{S}_{1}}$-casein remained intact; the $\beta$-casein fraction was more resistant to hydrolysis. The ripening time of Terrincho cheese can be predicted using 2 variables of normalized peak areas of $\alpha_{\mathrm{S} 1}$-casein and $\alpha_{\mathrm{S} 1}-\mathrm{I}$ peptide, and a constant; the estimation error is $2.5 \mathrm{~d}$. The $\mathrm{pH}$ 4.3-insoluble fraction of Terrincho and cheeses manufactured with bovine milk and with ovine milk combined with 2 levels of bovine milk (10 and $20 \%$ ) revealed different chromatographic and electrophoretic profiles, especially the $\alpha_{\mathrm{S1}}$-casein fraction. Similar proteolysis progress was observed, particularly in the percentage of casein fraction degradation. However, using both analytical methods, the detection of $10 \%$ bovine milk at $30 \mathrm{~d}$ of ripening was no longer possible as result of $\alpha_{\mathrm{S} 1}$-casein hydrolysis. The discriminate analysis applied to HPLC data indicated that at $30 \mathrm{~d}$ of ripening, differences between the casein fractions of Terrincho cheese and mixture cheeses were mainly from $\beta_{1}$-casein content. The function thus obtained was able to correctly classify all the samples according to cheese type. Using the descriptive sensory profile, Terrincho cheese at $30 \mathrm{~d}$ of ripening could be distinguished from bovine and mixture cheeses owing to its higher fracturability and adhesiveness and lower elasticity and hardness, which correlated with its lower total casein content.
\end{abstract}

Key words: cheese, proteolysis, caseins, high performance liquid chromatography

Received October 26, 2005.

Accepted January 11, 2006.

${ }^{1}$ Corresponding author: isabel.ferreira@ff.up.pt

\section{INTRODUCTION}

Terrincho cheese is an uncooked, pressed cheese made from raw whole ovine milk from "Churra da Terra Quente" breed in the regions of northern Portugal. The Protected Denomination of Origin (PDO) for this cheese falls within a very specific geographic region, and its manufacture is based on traditional methods. The making of Terrincho cheese is performed according to the regulations issued by the Denomination of Origin Regulatory Board. Terrincho cheese is produced by slowly draining the curds obtained upon coagulation via the action of animal rennet. No starter cultures are added. Terrincho is characterized as a cylinder-shaped (dishtype) cheese with a flat rind; its weight ranges between 0.8 and $1.2 \mathrm{~kg}$, and it has a straw-yellow color, a semisoft consistency, a slightly oily texture containing some holes, and a soft, very characteristic flavor. Because the cheese is made from raw milk, and for safety reasons, it requires a minimum ripening time of $30 \mathrm{~d}$ before cheese can be sold.

The average composition of Terrincho cheese is $45 \%$ total solids, $50 \mathrm{~g}$ of fat/100 $\mathrm{g}$ of DM, $40 \mathrm{~g}$ of protein/100 g of DM, and 2.5\% salt on a DM basis (Pinho et al., 2004a). A number of variable factors are known to affect the composition of ovine cheeses: breed, climate, variation in the physicochemical and microbiological composition of the milk, rennet type, and ripening conditions, such as ripening time, temperature, and relative humidity. All these factors affect cheese lipolysis and proteolysis and strongly contribute to flavor and texture development (Fox, 1989; Ordonez et al., 1997; Gaiaschi et al., 2000, 2001; Irigoyen et al., 2000; Marino et al., 2000; Sousa et al., 2001; Bustamante et al., 2003; Dave et al., 2003).

Previous studies on the lipolysis and proteolysis of Terrincho cheese have mostly focused on the characterization of its composition relating to microbiology, texture, and quantification of volatile free fatty acids and other volatile compounds, and have examined low primary proteolysis and production of free biogenic amines (Pinho et al., 2003, 2004a,b,c). Therefore, a detailed evaluation of the effect of ripening time on the break- 
down of the different caseins during ripening, along with the formation of peptides and other breakdown products of CN hydrolysis is necessary for a more complete characterization of the product (Veloso et al., 2004).

Analysis of proteolysis by nonspecific methods, for example, by quantification of nitrogen in different peptide and amino acid fractions, provides information about the degree of proteolysis in cheese ripening (Pinho et al., 2004c). Nevertheless, the results of these methods do not express well the complexity and specificity of proteolytic development during cheese ripening; namely, the evolution of the 4 major $\mathrm{CN}, \alpha_{\mathrm{S1}^{-}}, \alpha_{\mathrm{S2}^{-}}$, $\beta$-, and para $\kappa-\mathrm{CN}$, and their proteolytic products. Electrophoretic and chromatographic techniques, however, resolve proteins or groups of peptides and thereby provide proteolytic profiles that can give useful information about proteolysis extension, ripening time, and product authenticity (Restani et al., 1996a; Trujillo et al., 2000; Veloso et al., 2002a,b; Borková and Snáselová, 2005).

Adulteration of traditional ovine cheeses with bovine milk presents a problem for food monitoring and one solution for this problem is the analysis of milk proteins (Borková and Snáselová, 2005). However, the proteolysis that occurs during cheese ripening incurs a risk of complex formation and the formation of insoluble new compounds and smaller peptides that can interfere with evaluation of authenticity. Examples of these compounds are $\gamma-\mathrm{CN}$ and proteoso-peptone fragments of $\beta$ $\mathrm{CN}$, originating from the action of plasmin. The $\lambda-\mathrm{CN}$, presumably fragments of $\alpha_{\mathrm{S} 1}$-CN, glycomacropeptides, and para $\kappa$-CN, are the result of chymosin action (Borková and Snáselová, 2005).

To date, there have been reports on the use of chemometric analysis for evaluation of the proteolytic process in different types of cheese during ripening, as well as for predicting cheese ripening time (Pham and Nakai, 1984; Santamaría et al., 1986; García-Ruiz et al., 1998; Herrero-Martínez et al., 2000; Pripp et al., 2000). However, limited data are available on the application of multivariate statistical analysis to predict ripening time and authenticity of Terrincho cheeses. Previous studies carried out by our research group using small cheeses $(70 \mathrm{~g})$ indicated that HPLC profiles of the $\mathrm{pH}$ 4.3-insoluble fraction could be used not only to follow proteolysis but also to evaluate the authenticity of ewe cheeses (Veloso et al., 2004). However, differences may occur in ripening relating to cheese size variations, native microflora, and others. For that reason, further studies with Terrincho cheeses of real dimensions were performed for quantitative measurements of $\mathrm{CN}$ degradation in these cheeses.

The objective of the present study was to evaluate the proteolytic process during $30 \mathrm{~d}$ of ripening of Terrincho cheese based on the protein patterns obtained by HPLC of the $\mathrm{pH}$ 4.3-insoluble fractions. Chemometric analysis of the HPLC data was also used to predict the ripening time. Additionally, the influence of milk origin on proteolysis and cheese sensory characteristics was studied through evaluation of HPLC and urea-PAGE CN profiles during ripening of cheeses manufactured using the same methodology to guarantee Terrincho PDO authenticity.

\section{MATERIALS AND METHODS}

\section{Cheese Making}

A batch of Terrincho PDO cheeses was manufactured during the winter at a certified dairy plant, according to the traditional method. Briefly, prefiltered pure raw ewe's milk of the "Churra da Terra Quente" breed was heated to $35^{\circ} \mathrm{C}$, and coagulated with animal rennet derived from artisanal production; the curds were slightly drained and placed in molds, where they were subjected to pressure to help remove the remaining whey. The cheeses were salted upon unmolding and placed in ripening chambers held at 10 to $12^{\circ} \mathrm{C}$ and 88 to $89 \%$ relative humidity.

Simultaneously in the same dairy plant, 3 other batches of cheeses were manufactured according to Terrincho technology, one batch using raw bovine milk and 2 batches using mixtures of bovine and ovine raw milks [10 to $90 \%$ mixture (M1) and 20 to $80 \%$ mixture (M2) bovine to ovine, respectively]. These percentages were selected because use of less than $10 \%$ of bovine milk is not profitable economically, whereas use of more than $20 \%$ is easily detected by consumers.

From these 4 batches, groups of 2 cheeses were randomly taken at $0,7,14,21$, and $30 \mathrm{~d}$ of ripening and the $\mathrm{pH} 4.3$-insoluble fraction was assayed by HPLC and urea-PAGE. Cheeses from each batch at $30 \mathrm{~d}$ of ripening were used for sensory analysis; 40 cheeses were selected.

All cheeses were ripened locally under the aforementioned conditions. At each sampling time, cheeses were duly conditioned in refrigerated boxes and sent promptly to our laboratory. Two samples of each cheese were cut, labeled, and frozen at $-40^{\circ} \mathrm{C}$ pending analysis of the study parameters. The analyses were carried out in duplicate, so that 8 analyses were determined for each type of cheese on each of the collection dates.

Milk used for preparation of each batch of cheese was also analyzed for the chromatographic and electrophoretic profile of $\mathrm{pH}$ 4.3-insoluble fraction.

\section{Reagents and Protein Standards}

All reagents used were of analytical grade purity. Eluents for HPLC were filtered through $0.22-\mu \mathrm{m}$ NL 17 
filters (Whatman, Brentford, UK) and degassed under vacuum for at least 15 min before use.

Bovine casein, with a minimum purity of $75 \%$, determined by the method of Bradford (1976), was supplied by Sigma Chemical Co. (St. Louis, MO). Purified bovine $\alpha-, \beta-$, and $\kappa$-CN were obtained from Sigma Chemical Co., and had a minimum purity of 85,90 , and $80 \%$ (according to Sigma), respectively. Casein standards were dissolved in a mixture of $70 \%$ water and $30 \%$ acetonitrile (vol/vol) for HPLC analysis, and in deionized water at $\mathrm{pH} 10$ for electrophoretic assays.

\section{Chemical Analysis}

Analyses were performed using cheese samples that were thawed at 3 to $4^{\circ} \mathrm{C}$ for $12 \mathrm{~h}$. The $\mathrm{pH}$ was measured by inserting a combined $\mathrm{Ag}-\mathrm{AgCl}$ electrode into a comminuted sample according to the method of Berdague and Grappin (1987). Dry matter was evaluated using equipment from Scaltec Instruments GmbH (Goettingen, Germany).

\section{Caseins Extraction}

Isoelectric caseins were obtained by precipitation from $2.5 \mathrm{~g}$ of homogenized cheese in $15 \mathrm{~mL}$ of water by adding $1 M \mathrm{HCl}$ to $\mathrm{pH} 4.3$, followed by centrifugation at $4^{\circ} \mathrm{C}$ for $15 \mathrm{~min}$ at $3,000 \times \mathrm{g}$ to recover the precipitated caseins. To isolate the casein fraction completely from whey, the precipitate was washed once with $1 \mathrm{~m} M$ ammonia acetate buffer ( $\mathrm{pH} 4.3)$ and centrifuged at 3,000 $\times g$ for $10 \mathrm{~min}$, at $4^{\circ} \mathrm{C}$. This procedure was repeated twice. To remove the remaining fat, the sample was washed with acetone, and left to dry in a fume hood at room temperature. Finally, the dried, powdered casein was weighed, and stored in a desiccator at $8^{\circ} \mathrm{C}$ until analyzed. The dried powder was dissolved in a mixture of $70 \%$ water and $30 \%$ acetonitrile (vol/vol) and in deionized water at $\mathrm{pH} 10$ for the HPLC and electrophoretic analysis, respectively. Total casein content at each ripening time (expressed as $\mathrm{g}$ of casein/100 $\mathrm{g}$ of cheese) was measured from the weight of extracted caseins.

\section{HPLC Separations}

The chromatographic analysis was carried out in an analytical HPLC unit (Jasco, Tokyo, Japan) equipped with 2 type PU-980 pumps, a type UV-970 detector, and a type 7125 Rheodyne injector with a $20-\mu \mathrm{L}$ loop. Borwin PDA Controller software (JMBS Developpements, Grenoble, France) was also used. The column was a reversed-phase Chrompack P 300 RP column (Varian, Harbor City, CA) that contained polystyrenedivinylbenzene copolymer-based packing ( $8 \mu \mathrm{m}, 300 \AA$,
$150 \times 4.6 \mathrm{~mm}$ i.d. $)$; a Chrompack P RP $(24 \times 4.6 \mathrm{~mm}$ i.d.) precolumn was used.

Gradient elution was carried out with a mixture of 2 solvents. Solvent A consisted of $0.1 \%$ trifluoroacetic acid (TFA) in water and solvent B consisted of $0.1 \%$ TFA in $80 \%$ aqueous acetonitrile (vol/vol). Proteins were eluted with a series of linear gradients: $29 \%$ solvent B in solvent A during $5 \mathrm{~min}$, from 29 to $37 \% \mathrm{~B}$ over $5 \mathrm{~min}, 37$ to $54 \%$ solvent B over $15 \mathrm{~min}$, holding for 2 min, finishing with 54 to $100 \%$ of solvent B in 3 min, followed by $5 \mathrm{~min}$ for column reequilibration. The flow rate was $1.0 \mathrm{~mL} / \mathrm{min}$, the column temperature was $46 \pm 0.1^{\circ} \mathrm{C}$, and the detection wavelength was $280 \mathrm{~nm}$.

Peaks were characterized using caseins from bovine and ovine milk previously identified in our laboratory (Veloso et al., 2002b) according to previous identification (Visser et al., 1986). The areas under the 5 most representative peaks on the chromatogram, designated $\kappa$-CN (para $\kappa$-CN), $\alpha_{\mathrm{S} 1}-\mathrm{I}\left(\alpha_{\mathrm{S}^{1}}\right.$-I peptide), $\alpha_{\mathrm{S} 2}-\mathrm{CN}, \beta_{2}-\mathrm{CN}$, $\alpha_{\mathrm{S} 1}-\mathrm{CN}$, and $\beta_{1}-\mathrm{CN}$ in order of elution (Figure 1 ), were used to study the evolution of proteolytic process.

The repeatability of peak areas was assessed by replicate injections $(\mathrm{n}=10)$ of a standard mixture of $\alpha \mathrm{s}$ $\mathrm{CN}, \beta-\mathrm{CN}$, and $\kappa$-CN at $5 \mathrm{mg} / \mathrm{mL}$. Relative standard deviations were lower than $3.22 \%$.

\section{Urea-PAGE Analyses}

Polyacrylamide gel electrophoresis of casein samples was performed according to the method of Andrews (1983) with some modifications. The assays were carried out in a vertical vat (SE 250/260 Amersham Pharmacia Biotec, model Mighty, Amersham, Freiburg, Germany), using an EPS 301 power supply (Amersham Pharmacia Biotec).

The slab gels consisted of a $4 \%$ stacking gel and a $10 \%$ running gel. The stacking gel buffer was $0.06 \mathrm{M}$ Tris and 4.5 $M$ urea at $\mathrm{pH} 7.6$, and the resolving gel buffer was $0.76 M$ Tris and $9 M$ urea at $\mathrm{pH}$ 8.9. The electrophoresis buffer was a solution of $0.02 M$ Tris and $0.19 \mathrm{M}$ glycine. The run was performed at $4^{\circ} \mathrm{C}$ at 20 $\mathrm{mA}$ until the end of the stacking gel, followed by a current of $30 \mathrm{~mA}$. The gels were stained with Coomassie Brilliant Blue R250.

\section{Statistical Analyses}

Data were autoscaled before statistical analysis. This normalization involved dividing each value of a given variable by the standard deviation of all the values for this variable over the entire sample collection period (Garrido Frenich et al., 1995). After normalization, all variables had the same weight because they had a mean of zero and unitary variance. Exploration of data, de- 


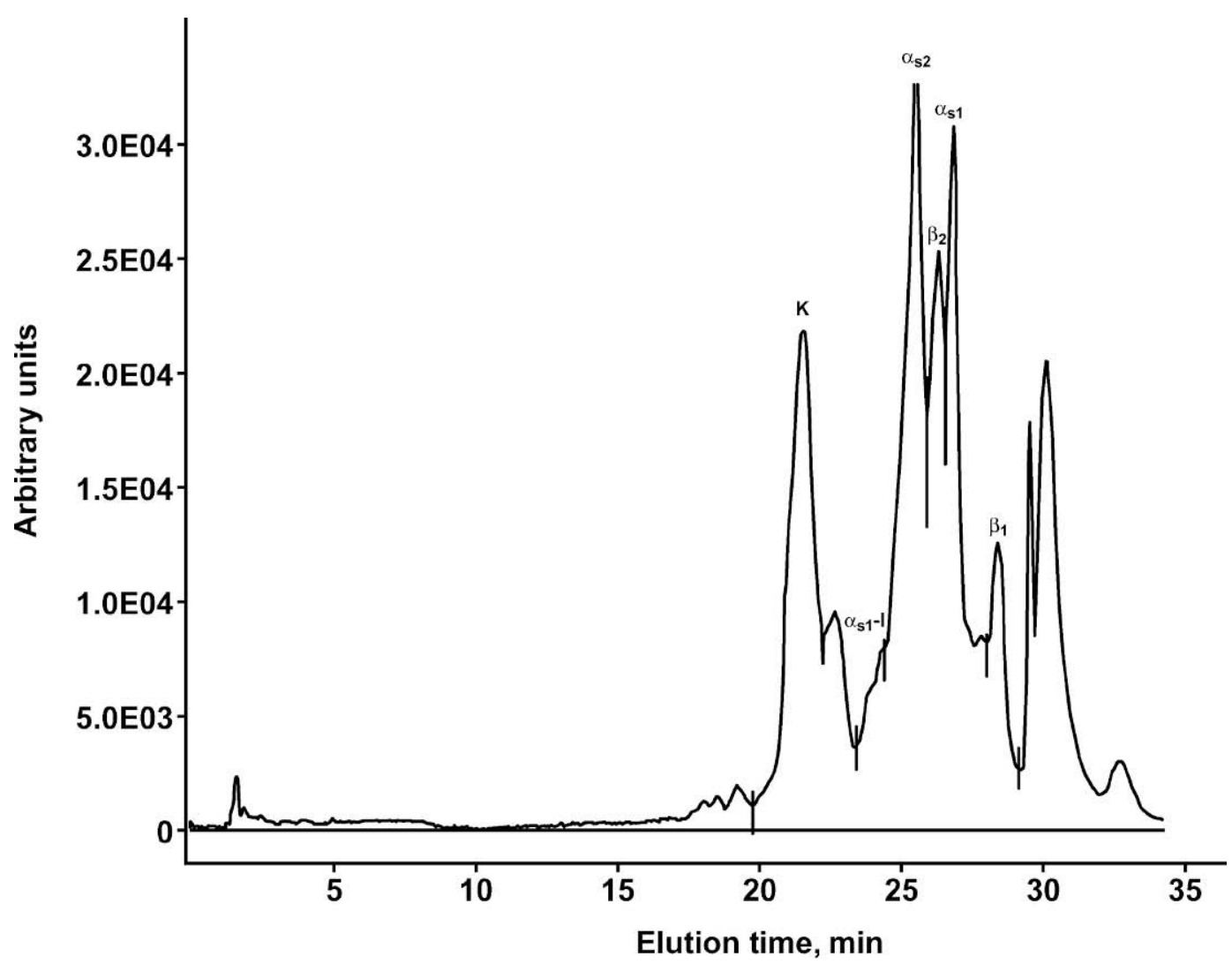

Figure 1. Chromatographic patterns (HPLC) of Terrincho cheese from $\mathrm{pH} 4.3$-insoluble fraction at $1 \mathrm{~d}$ of ripening. $\kappa=$ para- $\kappa$-casein; $\alpha_{\mathrm{S} 2}=\alpha_{\mathrm{S} 2}$-casein; $\alpha_{\mathrm{S} 1}=\alpha_{\mathrm{S} 1}$-casein; $\beta_{2}=\beta_{2}$-casein; $\beta_{1}=\beta_{1}$-casein.

scriptive statistics, $t$-test, and ANOVA with pairwise comparisons of mean values using Tukey's test, discriminant analysis, and multiple linear regressions were performed with SPSS for Windows version 13 (SPSS, Chicago, IL).

\section{Sensory Analysis}

Sensory analyses were performed by a jury of 20 panelists of both sexes who had been previously selected (ISO 8586-1, 1993). The taste panel evaluated texture, odor, and flavor attributes using a 7-point scale.

\section{RESULTS AND DISCUSSION}

\section{Proteolysis of Terrincho Cheese CN Fraction by Reverse-Phase HPLC}

Figure 1 indicates the chromatographic patterns obtained from Terrincho cheese $\mathrm{CN}$ at $1 \mathrm{~d}$ of ripening. The HPLC profiles of the Terrincho cheese $\mathrm{pH}$ 4.3-insoluble fraction at the beginning of ripening were similar to the profiles of $\mathrm{CN}$ from ovine milk (chromatograms not shown).
Two peaks observed in all the chromatograms near the 30-min retention time are the result of elution of small amounts of TFA, which adsorbs to the stationary phase and is eluted when eluent returns to initial composition. Similar behavior was observed by Elgar et al. (2000).

Only slight modifications were noted in the chromatograms at $7 \mathrm{~d}$ of ripening. However, important changes in chromatographic areas occurred between 7 and 30 $\mathrm{d}$ of ripening as shown in Table 1 .

Normalized data from the casein fractions of the 2 cheeses analyzed within each ripening time were compared using independent $t$-tests. As expected, differences were not significant $(P>0.05)$ between the 2 cheeses at each ripening time, revealing a similar proteolytic progress.

One-way ANOVA was used to verify whether the average values obtained for normalized peak areas for the major peaks, para $\kappa-\mathrm{CN}, \alpha_{\mathrm{S} 1}-\mathrm{I}$ peptide, $\alpha_{\mathrm{S} 2}-\mathrm{CN}, \alpha_{\mathrm{S} 1}-\mathrm{CN}$, $\beta_{2}-\mathrm{CN}$, and $\beta_{1}-\mathrm{CN}$, could be considered different or not during ripening. This was possible because data obtained for each ripening time were presented in general normal distribution $(P>0.05$; Shapiro-Wilk test $)$ and 
Table 1. Results of one-way ANOVA and posthoc (Tukey) test applied to data from Terrincho cheese proteolysis

\begin{tabular}{|c|c|c|c|c|c|c|}
\hline Variable & $\begin{array}{l}\text { Ripening } \\
\text { time, } \\
\text { d }\end{array}$ & $\mathrm{n}$ & $\begin{array}{l}\text { Average } \\
\text { normalized } \\
\text { area }\end{array}$ & SD & $F$ & $P$ \\
\hline$\kappa$-Casein & $\begin{array}{r}7 \\
14 \\
21 \\
30\end{array}$ & $\begin{array}{l}8 \\
8 \\
8 \\
8\end{array}$ & $\begin{array}{l}1.46^{\mathrm{a}} \\
0.97^{\mathrm{bc}} \\
1.07^{\mathrm{b}} \\
0.88^{\mathrm{c}}\end{array}$ & $\begin{array}{l}0.05 \\
0.02 \\
0.04 \\
0.06\end{array}$ & 32.96 & 0.000 \\
\hline$\alpha_{\mathrm{S} 1}$-I Peptide & $\begin{array}{r}7 \\
14 \\
21 \\
30\end{array}$ & $\begin{array}{l}8 \\
8 \\
8 \\
8\end{array}$ & $\begin{array}{l}0.40^{\mathrm{a}} \\
0.81^{\mathrm{b}} \\
1.26^{\mathrm{c}} \\
1.62^{\mathrm{c}}\end{array}$ & $\begin{array}{l}0.02 \\
0.03 \\
0.08 \\
0.09\end{array}$ & 30.15 & 0.000 \\
\hline$\alpha_{2}$-Casein & $\begin{array}{r}7 \\
14 \\
21 \\
30\end{array}$ & $\begin{array}{l}8 \\
8 \\
7 \\
8\end{array}$ & $\begin{array}{l}1.28^{\mathrm{a}} \\
0.63^{\mathrm{b}} \\
0.51^{\mathrm{c}} \\
0.43^{\mathrm{c}}\end{array}$ & $\begin{array}{l}0.03 \\
0.02 \\
0.03 \\
0.02\end{array}$ & 199.94 & 0.000 \\
\hline$\alpha_{1}$-Casein & $\begin{array}{r}7 \\
14 \\
21 \\
30\end{array}$ & $\begin{array}{l}8 \\
8 \\
8 \\
8\end{array}$ & $\begin{array}{l}0.97^{\mathrm{a}} \\
0.52^{\mathrm{b}} \\
0.46^{\mathrm{b}} \\
0.21^{\mathrm{c}}\end{array}$ & $\begin{array}{l}0.03 \\
0.02 \\
0.01 \\
0.05\end{array}$ & 72.11 & 0.000 \\
\hline$\beta_{2}$-Casein & $\begin{array}{r}7 \\
14 \\
21 \\
30\end{array}$ & $\begin{array}{l}8 \\
8 \\
8 \\
8\end{array}$ & $\begin{array}{l}0.34^{\mathrm{ab}} \\
0.29^{\mathrm{a}} \\
0.46^{\mathrm{b}} \\
0.34^{\mathrm{ab}}\end{array}$ & $\begin{array}{l}0.03 \\
0.02 \\
0.06 \\
0.02\end{array}$ & 7.26 & 0.001 \\
\hline$\beta_{1}$-Casein & $\begin{array}{r}7 \\
14 \\
21 \\
30\end{array}$ & $\begin{array}{l}8 \\
8 \\
7 \\
8\end{array}$ & $\begin{array}{l}2.03^{\mathrm{ab}} \\
1.94^{\mathrm{ab}} \\
2.32^{\mathrm{b}} \\
1.43^{\mathrm{a}}\end{array}$ & $\begin{array}{l}0.14 \\
0.11 \\
0.30 \\
0.07\end{array}$ & 4.358 & 0.012 \\
\hline
\end{tabular}

${ }^{\mathrm{a}-\mathrm{c}}$ For each variable, average values without common superscript are significantly different $(P<0.05)$.

homoscedasticity of variances $(P>0.05$; Levene test). Results obtained for ANOVA and posthoc tests (Tukey HSD) are shown in Table 1. It was concluded, with $95 \%$ confidence, that there were significant differences in the effect of ripening time of all quantified fractions (for para $\kappa$-CN, $\alpha_{\mathrm{S} 1}$-I peptide, $\alpha_{\mathrm{S} 2}-\mathrm{CN}, \alpha_{\mathrm{S} 1}-\mathrm{CN}, \beta_{1}-\mathrm{CN}$, and $\left.\beta_{2}-\mathrm{CN}\right)$. A significant reduction in the para $\kappa-\mathrm{CN}$, $\alpha_{\mathrm{S} 1}-\mathrm{CN}$, and $\alpha_{\mathrm{S} 2}-\mathrm{CN}$ contents depending on the ripening time was observed, together with an increase in $\alpha_{\mathrm{S} 1}-\mathrm{I}$ peptide. A reduction of $80 \%$ of $\alpha_{\mathrm{S1}}-\mathrm{CN}$ was observed during the $30 \mathrm{~d}$ of ripening. This is due to the action of residual rennet, together with the action of the hydrolytic enzymes of the microorganisms present in cheese. The primary site of chymosin action on $\alpha_{\mathrm{S} 1}-\mathrm{CN}$ is the $\mathrm{Phe}_{23}-\mathrm{Val}_{24}$ bond, with the appearance of $\alpha_{\mathrm{S1}}-\mathrm{I}$ peptide breakdown product; this peptide suffers further hydrolysis (Michaelidou et al., 1998; Irigoyen et al., 2000; Prieto et al., 2004). A reduction of $75 \%$ was observed for $\alpha_{\mathrm{S} 2}$-CN fraction, owing to chymosin action on these fractions (Singh et al., 1994). Some oscillations in $\beta_{1}$-CN and $\beta_{2}$-CN were observed, but without a significant decreasing trend. Thus, the fractions that corresponded to the $\beta$-CN region were less degraded than those that corresponded to the $\alpha_{\mathrm{S} 1}-\mathrm{CN}$ and $\alpha_{\mathrm{S} 2}-\mathrm{CN}$, which were hydrolyzed more quickly during the first stages of ripening. The greater resistance of $\beta$-CN to enzyme hydrolysis was already pointed out by several authors (Izco et al., 1999; Irigoyen et al., 2000). This fraction is mainly hydrolyzed by plasmin from milk (Gaiaschi et al., 2001) and it most likely does not significantly contribute to proteolysis of Terrincho cheese, owing to its $\mathrm{pH}$ between 5 and 6 (Lawrence et al., 1987).

A reduction of $40 \%$ was observed for fragments of para $\kappa-\mathrm{CN}$; this fraction is thought to be very resistant to further proteolysis after milk coagulation. However, peptides from $\kappa$-CN were isolated in Feta cheese, and its formation could be the result of the action of lactococcal proteinase at $\mathrm{Met}_{95}-\mathrm{Ala}_{96}$, which exhibits the characteristics of a susceptible cleavage site for such an enzyme (Reid et al., 1991; Michaelidou et al., 1998).

\section{Prediction of Terrincho Cheese Ripening Time by Multiple Linear Regression Analysis}

Terrincho cheese ripening time was estimated with stepwise variable selection involving the 6 variables by multiple linear regression analysis. The general formula of the estimation equation is as follows:

$$
\mathrm{y}=\mathrm{a}_{1} \mathrm{x}_{1}+\mathrm{a}_{2} \mathrm{x}_{2}+\ldots+\mathrm{a}_{\mathrm{n}} \mathrm{x}_{\mathrm{n}}+\varepsilon
$$

where $\mathrm{y}$ is cheese ripening time, $\mathrm{x}_{1}, \mathrm{x}_{2}, \ldots, \mathrm{x}_{\mathrm{n}}$ are the normalized areas of the major casein fractions, and $\varepsilon$ 


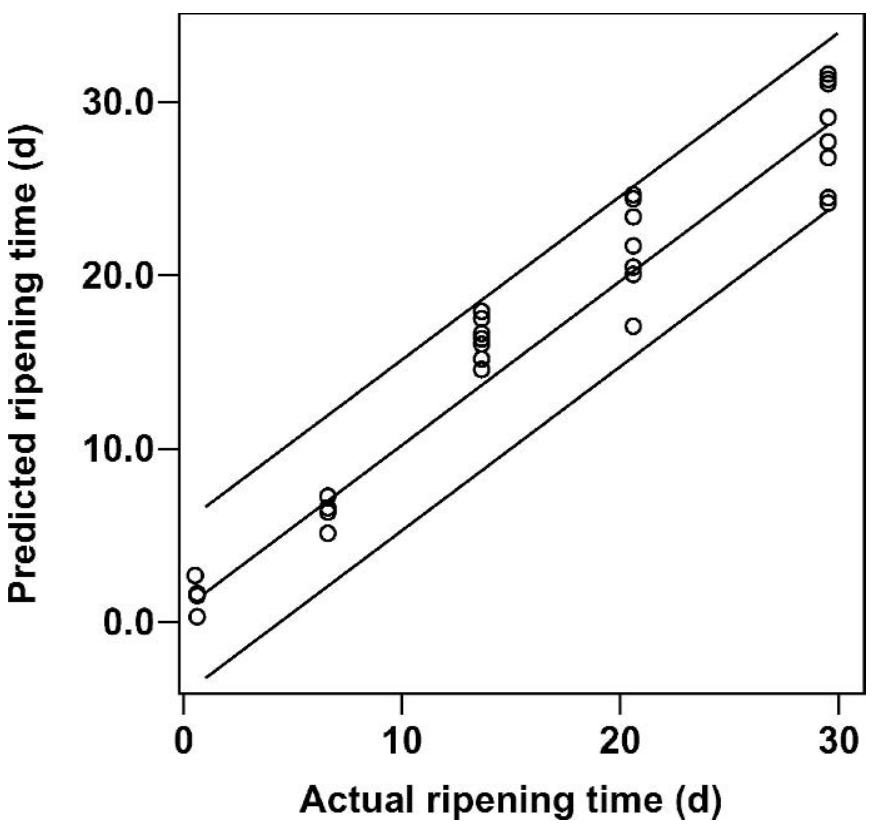

Figure 2. Prediction of ripening time for Terrincho cheeses; linear regression with $95.0 \%$ individual prediction interval; $\mathrm{y}=$ ripening time; $\mathrm{x}=$ major casein fractions normalized areas. $\mathrm{y}=13.56+10.7 \mathrm{x}$ $\alpha_{\mathrm{S} 1}$-I peptide $-11.8 \mathrm{x} \alpha_{\mathrm{S} 1}$-casein. $\mathrm{SE}=2.5, \mathrm{R}=0.92, \mathrm{n}=32, P<0.01$.

represents the errors or residuals of the model associated with the $\mathrm{y}$ values.

The correlation between the measured and estimated values is shown in Figure 2. The product ripening time can be estimated with 2 variables: normalized peak area of $\alpha_{\mathrm{S} 1}$-I peptide and $\alpha_{\mathrm{S} 1}-\mathrm{CN}$, as well as a constant (correlation coefficient $=0.917$ ). The estimation error is $2.5 \mathrm{~d}$. This error is lower than that obtained for prediction of Terrincho cheese ripening time based on texture and color parameters measured instrumentally (Pinho et al., 2004a). Our results are in agreement with other authors who identified the pattern of $\alpha_{\mathrm{S}}-\mathrm{CN}$ and related fragments as useful tools for the control of cheese ripening and quality (Gaiaschi et al., 2000).

\section{Reverse-Phase HPLC and Urea-PAGE Analysis to Evaluate Terrincho Cheese Authenticity}

Urea-PAGE and HPLC CN profiles, together with moisture, $\mathrm{pH}$, and total $\mathrm{CN}$ content of Terrincho cheese during ripening were compared with those of bovine and mixture cheeses (M1 and M2). Moisture and $\mathrm{pH}$ values influence cheese proteolysis and texture; similar behaviors were observed for Terrincho, bovine, and M1 and M2 cheeses. A decreasing trend was observed for $\mathrm{pH}$ values (from 6.5 to 5.1) up to $30 \mathrm{~d}$ of ripening; this trend can be associated with degradation of lactose and consequent organic acid production by lactic acid bacte- ria (Pinho et al., 2004c). Moisture decreased slightly as ripening time elapsed, ranging from 50 to $46 \%$.

The total $\mathrm{CN}$ content also decreased during ripening. At the beginning of ripening, total $\mathrm{CN}$ content was 19.5 $\pm 2.3,21.5 \pm 2.1,20.1 \pm 2.0$, and $20.5 \pm 1.8 \mathrm{~g} / 100 \mathrm{~g}$ of cheese, respectively, for Terrincho, bovine, and M1 and M2 cheeses. No significant differences were found between CN levels of the 4 types of cheese. In 30-d-old cheeses, Terrincho had significantly lower $\mathrm{CN}$ content than other cheeses, $14.1 \pm 0.6 \mathrm{~g} / 100 \mathrm{~g}$ of product, with no significant differences $(P<0.05)$ found among levels in $\mathrm{M} 1, \mathrm{M} 2$, and bovine cheeses $(17.5 \pm 1.1,16.1 \pm 0.9$, and $17.3 \pm 0.8 \mathrm{~g} / 100 \mathrm{~g}$ of product, respectively).

The HPLC profiles of the $\mathrm{pH} 4.3$ insoluble fractions of Terrincho, bovine, M1, and M2 cheeses with $7 \mathrm{~d}$ of ripening are shown in Figure 3. The chromatographic profile of Terrincho cheese CN was significantly different from that of bovine cheese $\mathrm{CN}$ concerning proportions of $\kappa$-CN, $\alpha_{\mathrm{S}}-\mathrm{CN}$, and $\beta$-CN fractions (24:47:29 and 10:56:34, respectively). Differences were also observed in retention times of $\alpha_{S^{-}} \mathrm{CN}$ from ovine and bovine milk. As a result of variations in retention times of ovine and bovine $\alpha_{\mathrm{S} 1}-\mathrm{CN}$, the chromatographic patterns of M1 and M2 cheeses were different compared with the Terrincho cheese $\mathrm{pH}$ 4.3-insoluble fraction, resulting in an overlap of bovine $\alpha_{\mathrm{S} 1}-\mathrm{CN}$ with ovine $\beta_{2}-\mathrm{CN}$ and $\alpha_{\mathrm{S} 1}-\mathrm{CN}$. This was more prominent in mixed cheeses with $20 \%$ bovine milk.

$\alpha_{\mathrm{S1}}$-Casein suffers significant hydrolysis during ripening; after $30 \mathrm{~d}$, this fraction in Terrincho cheese is very low. This was also observed in the $\mathrm{CN}$ fraction of M1 and M2 cheeses (Figure 4), which makes the detection of adulteration more difficult. The M2 cheeses had a higher content of bovine $\alpha_{\mathrm{S} 1}-\mathrm{CN}$; thus, this fraction was still overlapping ovine $\beta_{2}-\mathrm{CN}$ and $\alpha_{\mathrm{S} 1}-\mathrm{CN}$ at $30 \mathrm{~d}$ of ripening. However, the proteolysis progress will make the adulteration detection by observation of chromatographic profile more difficult at longer ripening times.

Figures 5 and 6 show the urea-PAGE separation of $\mathrm{pH}$ 4.3-insoluble fractions of ovine and bovine milk, and of Terrincho, bovine, and mixture cheeses, after manufacture and after $30 \mathrm{~d}$ of ripening, respectively. Identification of bands of major $\mathrm{CN}$ fractions was done by comparison with published urea-PAGE electrophoretograms obtained under comparable conditions (Fox and McSweeney, 1998). Detection of bovine $\alpha_{\mathrm{S} 1}-\mathrm{CN}$ is one of the oldest techniques to identify bovine milk addition to other types of milk, and bovine $\alpha_{\mathrm{S} 1}$-CN can be used as a marker for the presence of bovine milk in ovine milk and in cheeses at the beginning of ripening.

The results obtained show that using the urea-PAGE technique it was possible to identify the adulteration after $20 \mathrm{~d}$ of ripening based on the different migration 

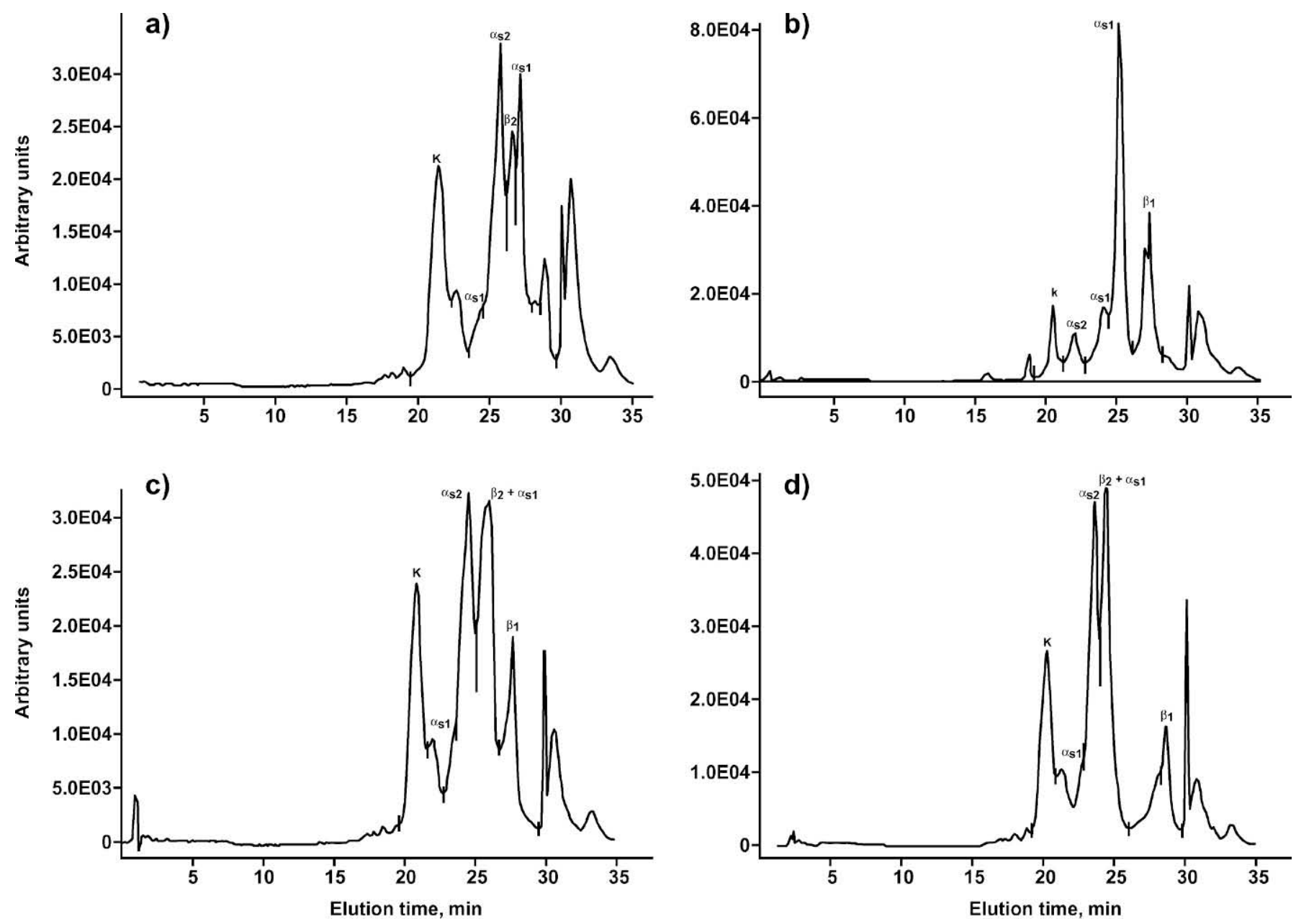

Figure 3. Chromatograms for cheese whole casein fraction after ripening for $7 \mathrm{~d}$ : a) Terrincho cheese; b) bovine; c) mixture 1 (10\% bovine

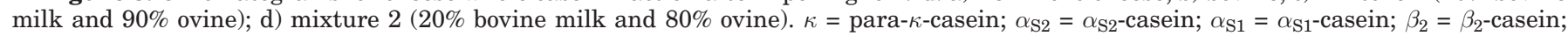
$\beta_{1}=\beta_{1}$-casein.

speeds of bovine and ovine $\alpha_{\mathrm{S} 1}-\mathrm{CN}$ (electrophoretograms not shown). However, in ripened cheeses showing a certain degree of proteolysis (with 30 or more days of ripening), this technique is no longer suitable for the detection of bovine milk, owing to hydrolysis of $\alpha_{\mathrm{S} 1}-\mathrm{CN}$, together with formation of several degradation products that have an electrophoretic mobility similar to that of bovine $\alpha_{\mathrm{S} 1}-\mathrm{CN}$. Similar electrophoretic profiles were obtained for Terrincho and mixture cheeses. Thus, urea-PAGE can be considered a reliable method for detection of bovine milk in ovine milk when no appreciable proteolytic changes have occurred, but should not be applied to mature Terrincho cheeses. In addition, urea-PAGE is useful as a separation method to study cheese proteolysis, but one of the main drawbacks of this method is that quantitative determination is not very accurate; hence, determinations must be interpreted with caution.
In a second stage of the study, discriminant analysis was applied to data obtained by HPLC from Terrincho, mixture, and bovine cheeses with $30 \mathrm{~d}$ of ripening, selecting only peaks corresponding to $\kappa$-CN, $\alpha_{\mathrm{S} 1}$-I peptide, $\alpha_{\mathrm{S} 2}-\mathrm{CN}$, and $\beta_{1}-\mathrm{CN}$; the peaks that overlapped in mixture cheeses were excluded. The discriminant analysis indicated that 3 variables contributed significantly to explaining the variability among the 4 types of cheese: $\kappa$-CN and $\alpha_{\mathrm{S} 1}$-I peptide were the major contributors to function 1 (loadings of -1,223 and 1,083) - the first was higher in Terrincho and mixture cheeses and the second in bovine cheeses (loading of 1,083 ) - and $\beta_{1}$-CN was positively correlated with function 2 (loading of 0,703 ). Plots of the samples in Figure 7 of the 2 main discriminant functions explained $98.0 \%$ of the total variance. Differences between Terrincho and mixture cheeses result from higher $\beta_{1}$-CN content in mixture cheeses, because this fraction is higher in bovine milk and more 

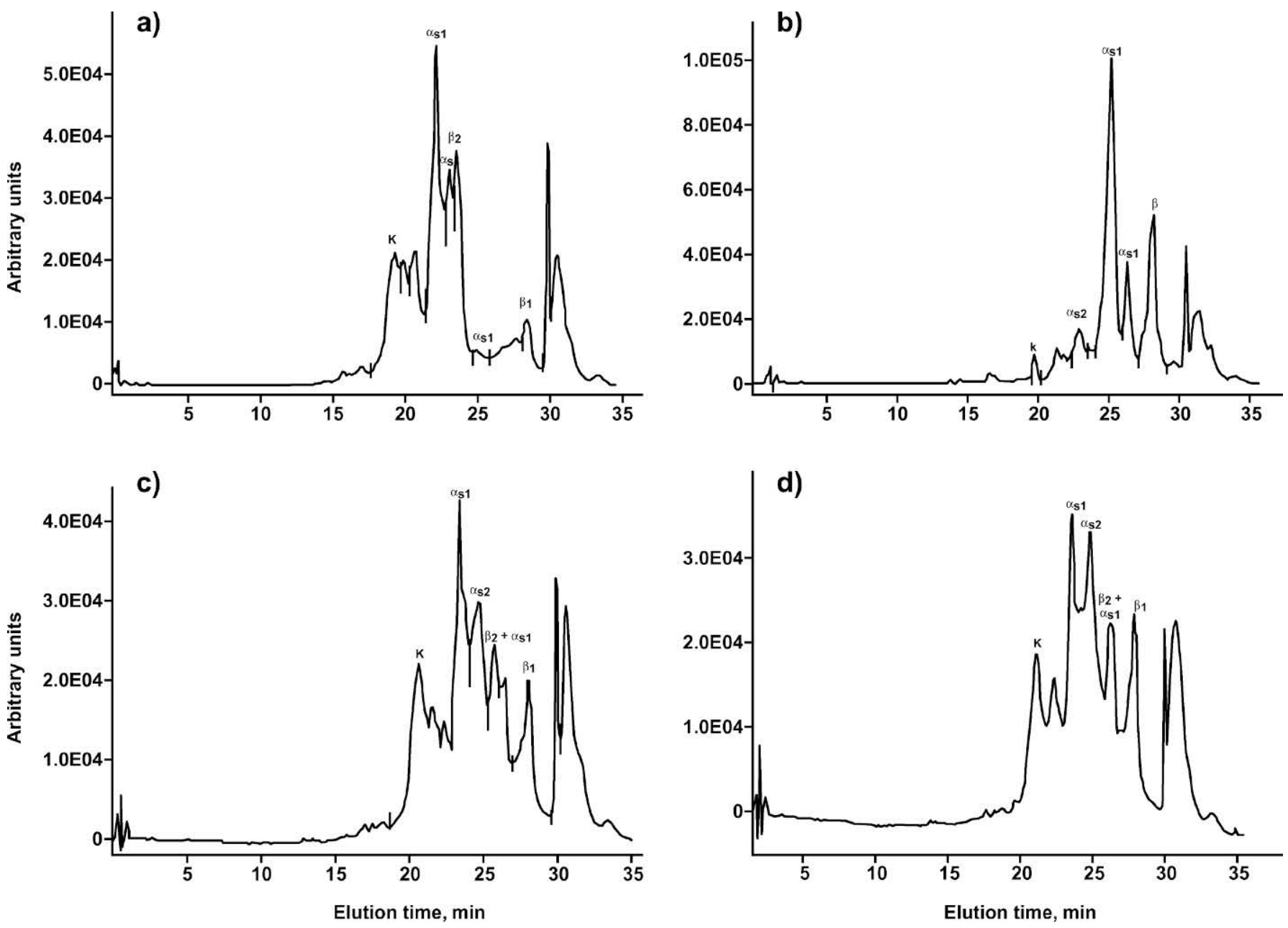

Figure 4. Chromatograms for cheese whole casein fraction after ripening for $30 \mathrm{~d}$ : a) Terrincho cheese; b) bovine; c) mixture 1 (10\% bovine milk and $90 \%$ ovine); d) mixture 2 (20\% bovine milk and $80 \%$ ovine). $\kappa=$ para- $\kappa$-casein; $\alpha_{\mathrm{S} 2}=\alpha_{\mathrm{S} 2^{-}}$-casein; $\alpha_{\mathrm{S} 1}=\alpha_{\mathrm{S} 1}$-casein; $\beta_{2}=\beta_{2^{-}}$ casein; $\beta_{1}=\beta_{1}$-casein.

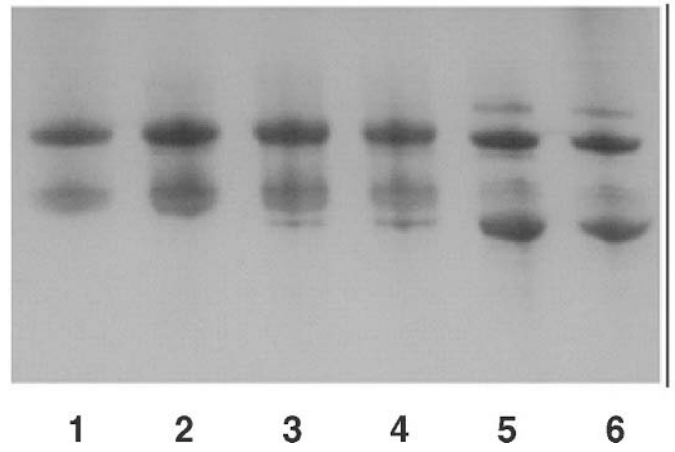

Figure 5. Urea-PAGE of the $\mathrm{pH}$ 4.3-insoluble fraction of ovine and bovine milks (lanes 1 and 6) and Terrincho cheese (lane 2), mixture 1 ( $10 \%$ bovine milk and $90 \%$ ovine; lane 3 ), and mixture 2 ( $20 \%$ bovine milk and $80 \%$ ovine; lane 4 ) cheeses, and bovine cheese (lane 5) after manufacture.

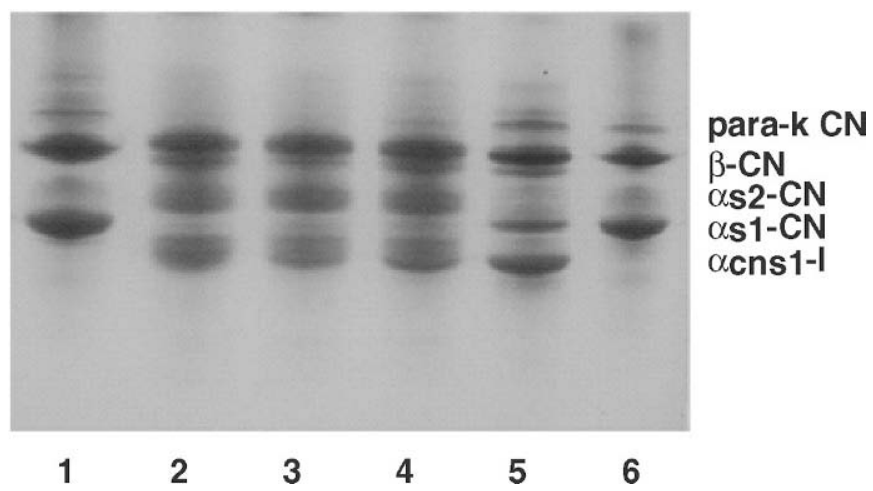

Figure 6. Urea-PAGE of the $\mathrm{pH}$ 4.3-insoluble fraction of ovine and bovine milks (lanes 1 and 6) and Terrincho cheese (lane 2), mixture 1 (10\% bovine milk and 90\% ovine; lane 3) and mixture 2 ( $20 \%$ bovine milk and $80 \%$ ovine; lane 4 ) cheeses, and bovine cheese (lane 5) after $30 \mathrm{~d}$ of ripening. 


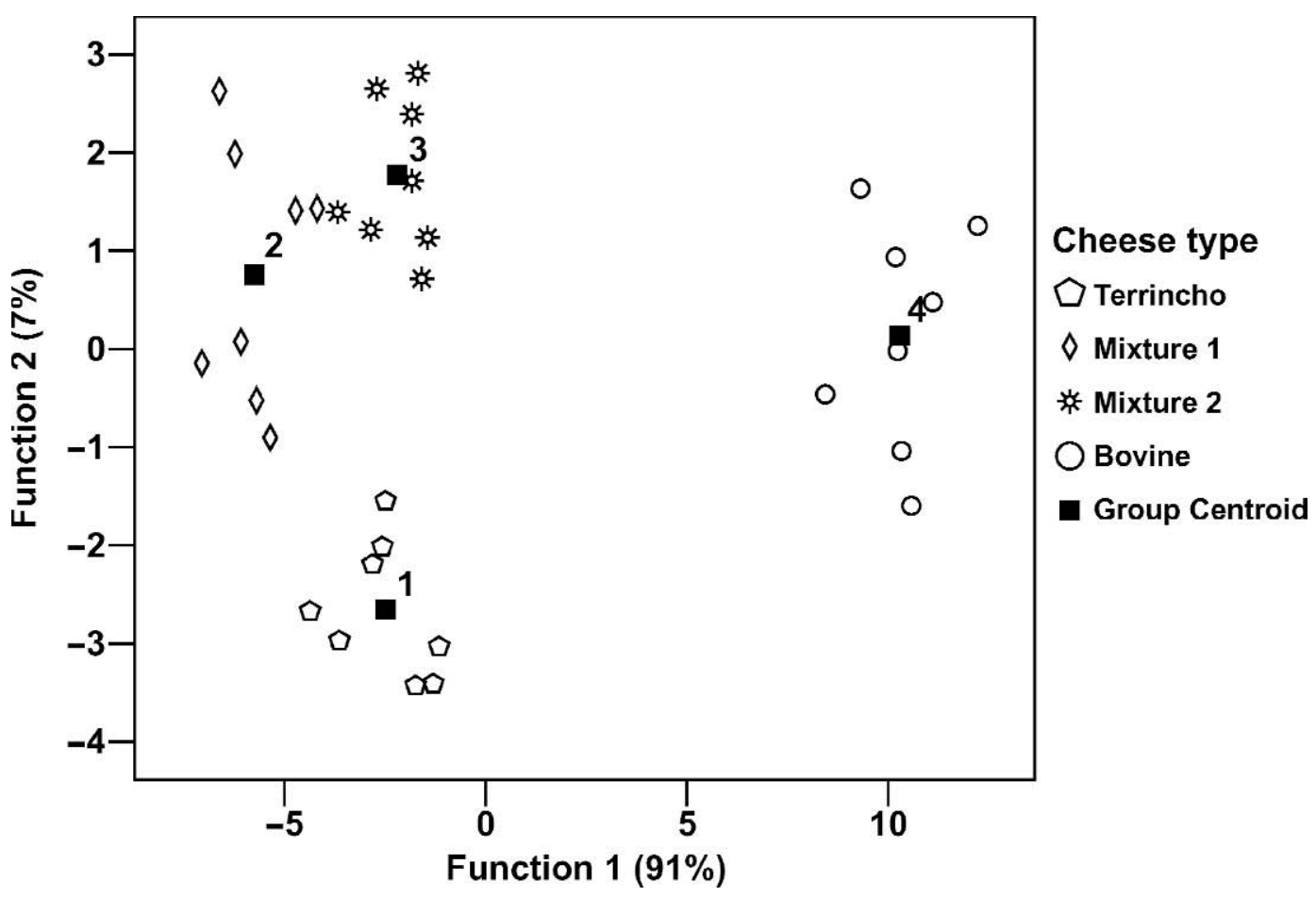

Figure 7. Canonical discriminant functions showing 4 groups of different types of cheeses classified by the 2 functions of the proposed model.

resistant to enzyme hydrolysis until $30 \mathrm{~d}$ of ripening. The function thus obtained was able to correctly classify all the samples according to cheese type.

\section{Influence of Milk Origin on Cheese Sensory Characteristics}

The ANOVA performed using the sensory attribute scores indicated significant differences in some of the Terrincho cheese attributes compared with those of mixture and bovine cheeses. However, no significant differences were found between M1 and M2 cheeses; thus, sensory attribute scores from these cheeses were analyzed together. In general, data within each cheese attribute were symmetric and mesokurtic. The aforementioned ANOVA indicated that no significant differences were observed for saltiness and rancidity; however, significant differences were noted for all other attributes. Good panel performance was verified to establish Terrincho cheese descriptive sensory profile (Figure 8). This cheese was distinguished from mixture and bovine cheeses because of its higher intensity of odor and aroma (especially animal aroma) and higher acidity and astringency. Bovine cheeses had the lowest scores for these attributes and mixture cheeses were in the middle. In terms of texture, Terrincho cheese exhibited higher levels of fracturability and adhesiveness and lower elasticity and hardness; these parame- ters were correlated with its lower total CN content. Izco et al. (1999) described reduced elasticity in ovine cheeses with increased proteolysis.

According to Lawrence et al. (1987), a lower ratio between moisture content and total $\mathrm{CN}$ results in a firmer CN matrix. This ratio was higher in Terrincho cheese, explaining its lower hardness and higher fracturability and adhesiveness because the $\mathrm{CN}$ matrix is weaker. However, the effect of proteolysis in softening, as discussed recently by Dave et al. (2003) appears to be less important than the fat content.

\section{CONCLUSIONS}

Data presented in this and our previous paper (Veloso et al., 2004) has contributed to deepening the knowledge on the casein degradation of Terrincho cheese throughout ripening. In particular, the relationship between $\mathrm{CN}$ fraction composition, ripening time, milk origin, and cheese sensory characteristics were approached in this paper in a statistically validated manner.

High performance liquid chromatography is well suited to analyze the $\mathrm{pH}$ 4.3-insoluble fraction during cheese ripening. The method was able to quantify $\mathrm{CN}$ degradation and to study the effect of the ripening time on the proteolytic process in Terrincho cheese. 


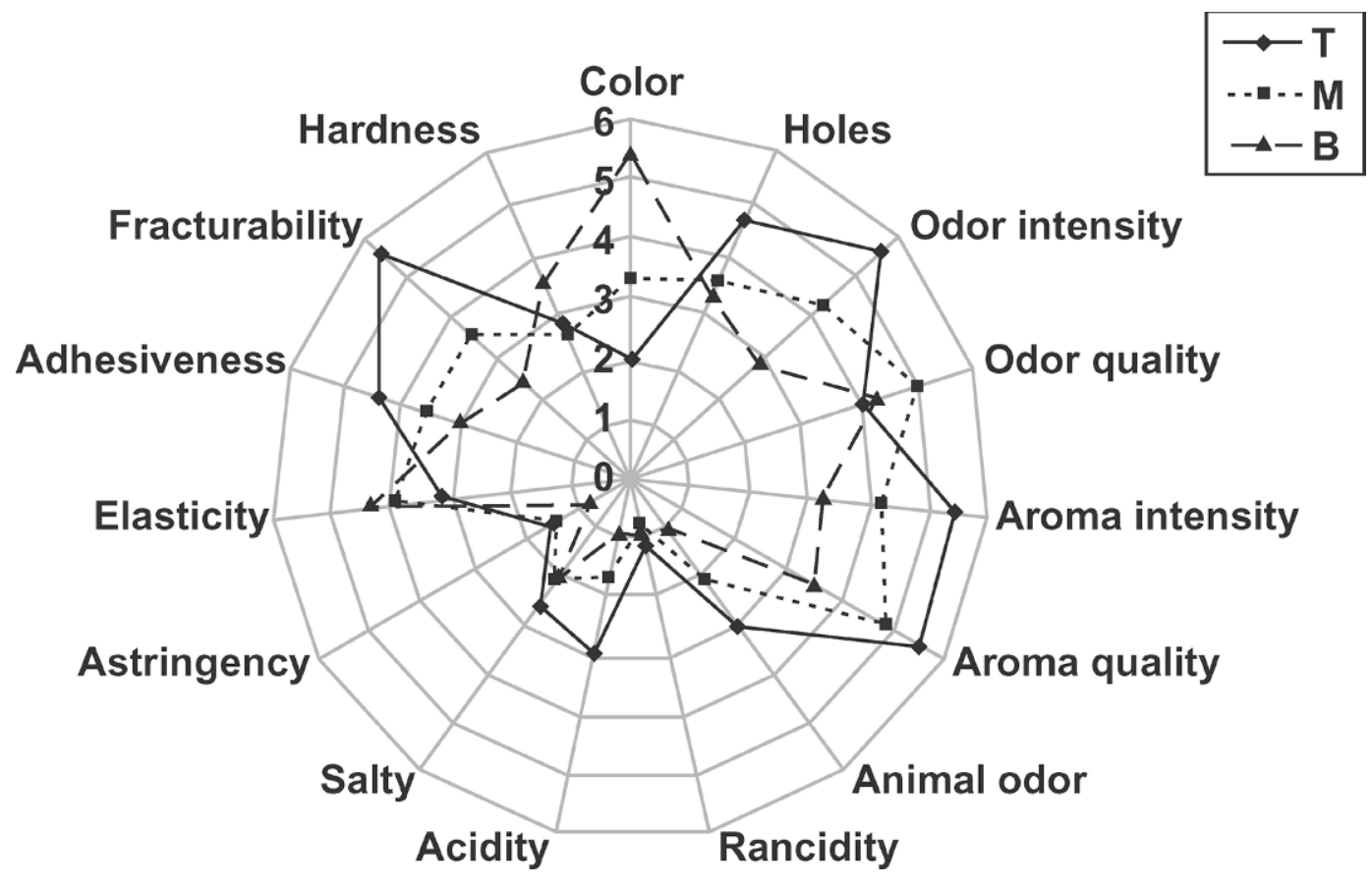

Figure 8. Mean scores obtained by 20 panelists for the 15 attributes assessed in Terrincho (T), mixture 2 (M), and bovine (B) cheeses.

During the $30 \mathrm{~d}$ of Terrincho cheese ripening, a relatively high resistance of $\beta$-CN to hydrolysis by residual chymosin and microorganisms present in cheese was verified, as observed in most cheeses (Fox, 1989). In contrast, the hydrolysis of $\alpha_{\mathrm{S} 1}-\mathrm{CN}$ and $\alpha_{\mathrm{S} 2}$-CN was significant. In 30-d-old cheeses, only $20 \%$ of $\alpha_{\mathrm{S}_{1}}$-CN remained intact. The ripening time of Terrincho cheese can be predicted using the 2 variables of normalized peak areas of $\alpha_{\mathrm{S} 1}-\mathrm{CN}$ and $\alpha_{\mathrm{S} 1}$-I peptide, and a constant. The estimation error was $2.5 \mathrm{~d}$. In spite of the different proportions of $\mathrm{CN}$ fractions in bovine and mixture cheeses, the evolution of cheese proteolysis followed a similar trend. Differences between Terrincho and mixture cheeses result from higher $\beta_{1}$-CN content in mixture cheeses. The $\alpha_{\mathrm{S} 1}-\mathrm{CN}$ fraction related to Terrincho cheese ripening time, and $\beta_{1}$ - CN fraction was a marker for Terrincho cheese authenticity.

Terrincho cheese descriptive sensory profile at $30 \mathrm{~d}$ of ripening was distinguished from bovine and mixture cheeses owing to its higher fracturability and adhesiveness and lower elasticity and hardness; these parameters were correlated with its lower total CN content.

In conclusion, chemometric analysis of HPLC proteolytic profiles has been shown to be a powerful method to examine the biochemical process of proteolysis and to predict the ripening time and authenticity of Terrincho cheese.

\section{REFERENCES}

Andrews, A. T. 1983. Proteinases in normal bovine milk and their action on caseins. J. Dairy Res. 50:45-55.

Berdague, J. L., and R. Grappin. 1987. Affinage et cualité du Gruyère de Comté. II. Influence de l'affinage sur l' évolution des caractéristique physico-chimimiques des fromages. Lait 67:237-241.

Borková, M., and J. Snáselová. 2005. Possibilities of different animal milk detection in milk detection in milk and dairy products-A review. Czech. J. Food Sci. 23:41-50.

Bradford, M. M. 1976. A rapid and sensitive method for the quantitation of microgram quantities of protein utilizing the principle of protein-dye-binding. Anal. Biochem. 72:248-254.

Bustamante, M. A., M. Virto, M. Aramburu, L. J. R. Barron, F. J. Pérez-Elortondo, M. Albisu, and M. de Renobales. 2003. Lamb rennet paste in ovine cheese (Idiazabal) manufacture. Proteolysis and relationship between analytical and sensory parameters. Int. Dairy J. 13:547-557.

Dave, R. I., D. J. McMahon, C. J. Oberg, and J. R. Broadbent. 2003. Influence of coagulant level on proteolysis and functionality of Mozzarella cheeses made using direct acidification. J. Dairy Sci. 86:114-126.

Elgar, D. F., C. S. Norris, J. S. Ayers, M. Pritchard, D. E. Otter, and K. P. Palmano. 2000. Simultaneous separation and quantification of the major bovine whey proteins including proteose peptone and caseinomacropeptide by reversed-phase high performance liquid chromatography. J. Chromatogr. A 878:183-196.

Fox, P. F., and P. L. H. McSweeney. 1998. Milk proteins. Pages 146-238 in Dairy Chemistry and Biochemistry. 1st ed. Blackie Academic \& Professional, London, UK.

Fox, P. F. 1989. Proteolysis during cheese manufacture and ripening. J. Dairy Sci. 72:1379-1400.

García-Ruiz, A., L. Cabezas, P. J. Martín-Alvárez, and D. Cabezudo. 1998. Prediction of the ripening times of Manchego cheese using multivariate statistical analysis: A preliminary study. Z. Lebensm. Unters. Forsch. 206:382-386. 
Garrido Frenich, A., D. Jouan-Rimbaud, D. L. Massart, S. Kuttatharmmakul, M. Martinez Galera, and J. L. Martinez Vidal. 1995. Wavelength selection method for multicomponent spectroscopic determinations using partial least squares. Analyst 120:27872792.

Gaiaschi, A., B. Beretta, C. Poiesi, A. Conti, M. G. Giuffrida, C. L. Galli, and P. Restani. 2000. Proteolysis of $\alpha_{\mathrm{S}}$-casein as a marker of Grana Padano cheese ripening. J. Dairy Sci. 83:2733-2739.

Gaiaschi, A., B. Beretta, C. Poiesi, A. Conti, M. G. Giuffrida, C. L. Galli, and P. Restani. 2001. Proteolysis of $\beta$-casein as a marker of Grana Padano cheese ripening. J. Dairy Sci. 84:60-65.

Herrero-Martínez, J. M., E. F. Simó-Alfonso, G. Ramis-Ramos, C. Gelfi, and P. G. Righetti. 2000. Determination of cow's milk and ripening time in nonbovine cheeses by capillary electrophoresis of the ethanol-water protein fraction. Electrophoresis 21:633-640.

Irigoyen, A., J. M. Izco, F. C. Ibáñez, and P. Torre. 2000. Evaluation of the effect of rennet type on casein proteolysis in an ovine milk cheese by means of capillary electrophoresis. J. Chromatogr. A. 881:59-67.

ISO. 1993. 8586-1. Analyse sensorielle, Guide général pour la sélection, l'entraînement et le contrôle des sujets. Partie 1: Sujets qualifiés. In Contrôle de la qualité des produits alimentarairesAnalyse sensorielle, 5e édition (1995). ISO, Geneva, Switzerland.

Izco, J. M., P. Torre, and Y. Barcina. 1999. Capillary electrophoresis: Evaluation of the effect of added enzymes on casein proteolysis during the ripening of a ewe's milk cheese. Adv. Food Sci. $21: 110-116$.

Lawrence, R. C., L. K. Creamer, and J. Gilles. 1987. Texture development during cheese ripening. J. Dairy Sci. 70:1748-1760.

Marino, M., M. Maifreni, S. Moret, and G. Rondinini. 2000. The capacity of Enterobacteriaceae species to produce biogenic amines in cheese. Lett. Appl. Microbiol. 31:169-173.

Michaelidou, A., E. Alichanidis, H. Urlaub, A. Polychroniadou, and G. K. Zerfiridis. 1998. Isolation and identification of some major water-soluble peptides in Feta cheese. J. Dairy Sci. 81:3109-3116.

Ordonez, A. I., C. I. Francisco, P. Torres, and Y. Barcina. 1997. Characterization of the casein hydrolysis of Idiazábal cheese manufactured from ovine milk. J. Dairy Sci. 81:2089-2095.

Pham, A., and S. Nakai. 1984. Application of stepwise discriminant analysis to high-pressure liquid chromatography profiles of water extract for judging ripening of Cheddar cheese. J. Dairy Sci. 67:1390-1396.

Pinho, O., I. M. P. L. O. Ferreira, and M. Ferreira. 2003. Quantification of short-chain free fatty acids in "Terrincho" ewe cheese: Intravarietal comparison. J. Dairy Sci. 86:3102-3109.

Pinho, O., I. M. P. L. O. Ferreira, and M. Ferreira. 2004b. Discriminate analysis of the volatile fraction from "Terrincho" ewe cheese: Correlation with flavour characteristics. Int. Dairy J. 14:455-464.

Pinho, O., E. Mendes, M. M. Alves, and I. M. P. L. O. Ferreira. 2004a Chemical, physical and sensorial characteristics of "Terrincho" ewe cheese. Changes during ripening and intravarietal comparison. J. Dairy Sci. 87:249-257.

Pinho, O., A. I. E. Pintado, A. M. P. Gomes, M. M. E. Pintado, F. X. Malcata, and I.M.P.L.V.O. Ferreira. 2004c. Interrelationships among microbiological, physicochemical, and biochemical properties of terrincho cheese, with emphasis on biogenic amines. J. Food Prot. 67:2779-2785.

Prieto, B., I. Franco, J. M. Fresno, J. G. Prieto, A. Bernardo, and J. Carballo. 2004. Effect of ripening time and type of rennet (farmhouse rennet from kid or commercial calf) on proteolysis during ripening of León cow milk cheese. Food Chem. 85:389-398.

Pripp, A. H., L. Stepaniak, and T. Sorhaug. 2000. Chemometrical analysis of proteolytic profiles during cheeses ripening. Int. Dairy J. 10:249-253.

Reid, J. R., C. H. Moore, G. G. Midwinter, and G. G. Pritchard. 1991. Action of a cell wall proteinase from Lactococcus lactis subsp. cremoris SK11 on bovine $\alpha_{\mathrm{S} 1}$-casein Appl. Microbiol. Biotechnol. 35:222-227.

Restani, P., T. Velonà, A. Carpen, M. Duranti, and C. L. Galli. 1996a. $\gamma$-Casein as a marker of ripening and/or quality of Grana Padano cheese. J. Agric. Food Chem. 44:2026-2029.

Santamaría, G., M. Ramos, and J. A. Ordonez. 1986. Application of linear-discriminant analysis to different proteolysis parameters for assessing the ripening of Manchego cheese. Food Chem. 19:225-234.

Singh, T. K., P. F. Fox, P. Hojrup, and A. Healy. 1994. A scheme for the fractionation of cheese nitrogen and identification of principal peptides. Int. Dairy J. 4:111-122.

Sousa, M. J., Y. Ardo, and P. L. H. McSweeney. 2001. Advances in the study of proteolysis during cheese ripening. Int. Dairy J. $11: 327-345$.

Trujillo, A. J., C. Isidre, and G. Buenaventura. 2000. Analysis of major ovine milk proteins by reversed-phase high-performance liquid chromatography and flow injection analysis with electrospray ionization mass spectrometry. J. Chromatogr. A 870:371-380.

Veloso, A. C. A., N. Teixeira, I. M. P. L. V. O. Ferreira, and M. A. Ferreira. 2002a. Detecção de adulterações em produtos alimentares contendo leite e/ou proteínas lácteas. Quim. Nova 25:609-615.

Veloso, A. C. A., N. Teixeira, and I. M. P. L. V. O. Ferreira. 2002b. Separation and quantification of the major caseins fractions by reverse-phase high performance liquid chromatography and ureapolyacrylamide gel electrophoresis-Detection of milk adulterations. J. Chromatogr. A. 967:209-218.

Veloso, A. C. A., N. Teixeira, A. M. Peres, A. Mendonç, and I. M. P. L. V. O. Ferreira. 2004. Evaluation of cheese authenticity and proteolysis by HPLC and urea-polyacrylamide gel electrophoresis. Food Chem. 87:289-295.

Visser, S., K. J. Slangen, and H. S. Rollema. 1986. High-performance liquid chromatography of bovine caseins with the application of various stationary phases. Milchwissenschaft 41:559-562. 